\title{
Collaborative Customers and Partners: The Ups and Downs of Their Influence on Firm Technology Competence for New Product Development
}

\author{
Janet K. Tinoco \\ Embry-Riddle Aeronautical University \\ Scott C. Ambrose \\ Embry-Riddle Aeronautical University
}

High technology organizations benefit from collaborative contributions of current customers, lead users, and major suppliers. New knowledge from these stakeholders propel firms to push technology competence for new product development. However, collaborations with these entities may also negatively impact the firm's technology competence. Using data collected from high technology manufacturers, a model is tested which analyzes both curvilinear and linear influences on competence. Results support the curvilinear influence of lead user collaboration on technology competence, as well as positive linear influences of customer and supplier collaboration. Subsequently, we find technology competence has a positive influence on firm performance.

\section{INTRODUCTION}

Network collaborations are often sought for their benefits through technology co-development, through the pooling and transfer of knowledge, and through cooperative creation of new products (Dyer, 1998; Gulati, 1998; Kogut, 1988; Varadarajan \& Jayachandran, 1999). Optimizing collaborations with external partners is key for generating a competitive advantage in the arena of new product development (NPD) and innovation. "When the knowledge base of an industry is both complex and expanding and the sources of expertise are widely dispersed, the locus of innovation will be found in networks of learning..." (Powell, Koput \& Smith-Doerr, 1996). New ideas, information, and knowledge can be tapped and absorbed into the firm through external networks of collaborations, impacting the firm's need to grow its technology competence for NPD.

Technology expertise, skills and knowledge form a critical core competency for firms, especially for those in turbulent high technology industries where sustaining competitive advantage is an unending challenge. Extant research supports that current and potential customers, lead users, and other outside organizations, such as a firm's major suppliers, can heavily influence NPD (e.g. Chang \& Taylor, 2016; Franke, von Hippel \& Schreier, 2006; Wind \& Mahajan, 1997) with new ideas and creative technological solutions. Yet, their impacts can be felt beyond product development processes and deep into the core of the firm's competencies. Collaborative contributions from these outside stakeholders can also push the firm to gain new technology competence in areas otherwise left uncharted. This competence, in part achieved via integration of knowledge obtained through network collaborations, is indispensable for firms seeking successful innovations that lead to competitive advantage. However, extant research suggests that 
there are contingencies and limitations to the positive influences these entities have on NPD and innovation (e.g. Chang \& Taylor, 2016; Lilien, Morrison, Searls, Sonmack \& von Hippel, 2002). As such, their influences on technology competence may also have limitations. Teasing out potential negative or damaging effects stemming from the firm's collaboration network of customers and key suppliers would aid companies in their integration of knowledge into competence development and in product development decision-making and strategies.

Against this backdrop, this exploratory study seeks to improve our collective understanding of both the benefits and limitations of the aforementioned collaborative relationships, specifically in high technology manufacturing industries where shortened product life cycles push the state of the art in technology expertise. Our key research question is as follows: Is there a limit as to the positive impacts one or more of these collaborative relationships have on the firm's level of technology competence? We propose that the impacts are curvilinear in form (inverse $U$ ), but we also offer competing hypotheses that the relationships progress in a positive linear manner. Per Armstrong, Brodie and Parsons (2001) competing hypotheses are useful in marketing and appropriate when prior knowledge leads to more than one explanation.

The key contributions of this article are three-fold. First, we seek to uncover empirical support that there are potential negative consequences on a firm's technology expertise decisions when it excessively relies on one or more collaborative relationships with customers, lead users, and suppliers. To date, while there is substantive research on customer participation on NPD (e.g. Chang \& Taylor, 2016), there is little research on the impacts of these relationships on a firm's technology competence. Second, most extant innovation studies have not tested for curvilinear effects; hence, it is important to further probe for potential limitations of this nature associated with external collaborative efforts (Greco, Grimaldi \& Cricelli, 2015). Third, we seek to extend the knowledge of academia and practitioners alike on what makes a successful collaborative environment, especially one in which marketing plays a central role in connecting to outside entities.

\section{CONCEPTUAL MODEL AND HYPOTHESES}

Our conceptual model in Figure 1 is theoretically grounded in organizational learning (March, 1991) for NPD and innovation, focusing on collaborative business processes and their impacts to technology competence. With this focus, we view collaborations through multiple lenses: current customers, lead users, and major suppliers to the firm. Each of these key outside stakeholders potentially impacts technology competence as new knowledge is obtained, coordinated, and integrated to aid or hinder organizational learning and competence development. 


\section{FIGURE 1 \\ CONCEPTUAL MODEL OF COLLABORATION INFLUENCE ON TECHNOLOGY COMPETENCE AND SUBSEQUENT IMPACTS TO FIRM PERFORMANCE}

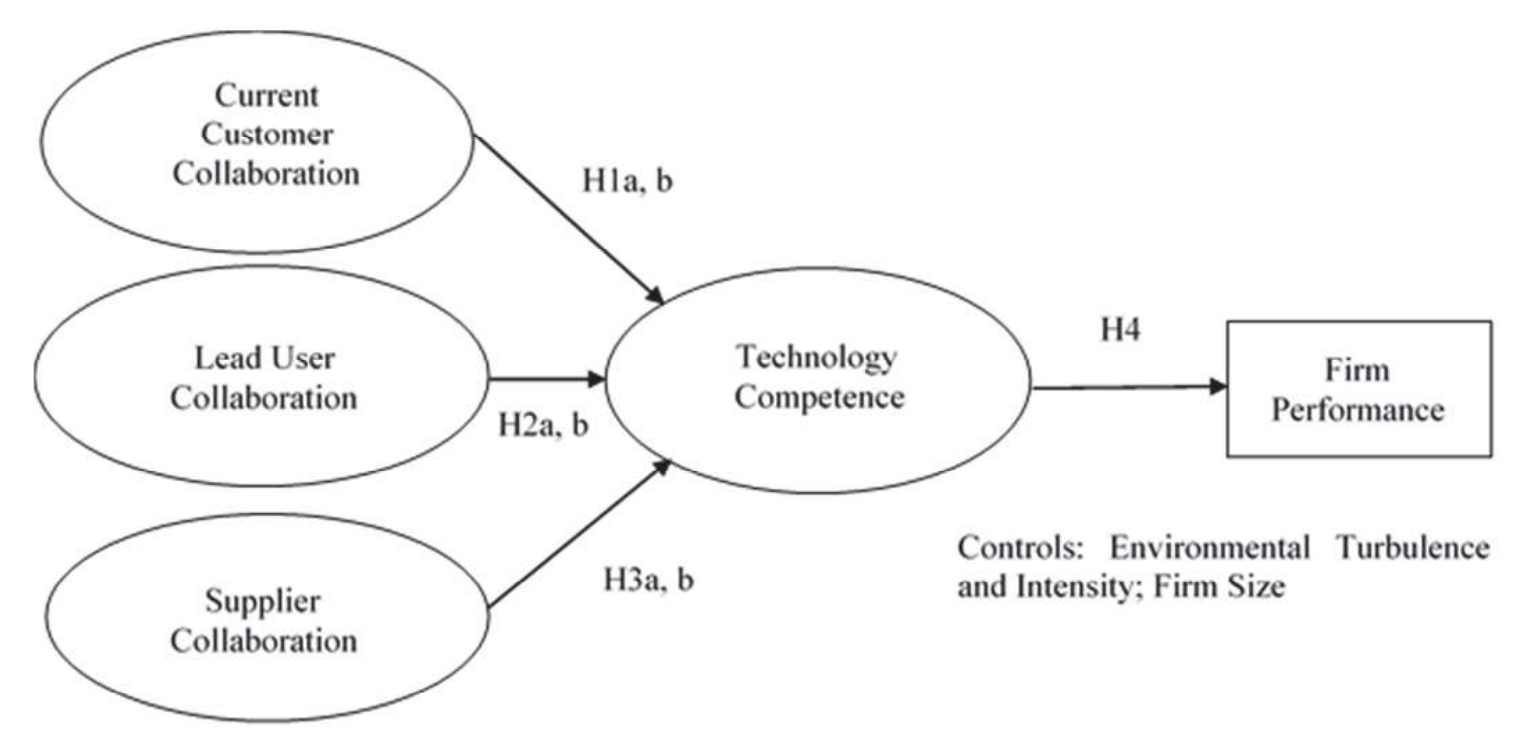

In our model, we define current customer collaboration as the "set of behavioral activities that generates customer knowledge from current customers pertaining to their needs for new product innovations" (Li \& Calantone, 1998). Meanwhile, we define lead user collaboration as a set of behavioral activities that generates knowledge from lead users pertaining to their current and potential needs for new product innovations (Wind \& Mahajan, 1997). Supplier collaboration is defined as the channel bonding activities in which durable collaborative relationships with channel members are created via activities of communication, joint problem solving, and product conceptualization and development between the parties (Day, 1994). Among channel members, we focus on major suppliers to the firm.

Our central construct, technology competence, is defined as the technological skills, knowledge, and experience resident within the firm that are necessary to design new product innovation (e.g. Hamel \& Prahalad, 1994). In this research, it is defined relative to the frontier such that organizations with high technology competence are closer to the technology frontier than those with lower technology competence. Technology competence plays a significant role in the development and design of new product innovations (e.g. Tinoco, 2014). Finally, firm performance is defined in terms of market share, sales growth, return on sales, and profitability.

In our model, we argue that collaborations with these stakeholders have the potential for both positive and negative impacts on the firm's technology competence development towards state of the art. The challenges of knowledge integration and learning, characteristics of the stakeholder groups under study, along with the possibility of firm over-reliance on one or more of these relationships may eventually hinder the firm from pushing the technological frontier, ultimately eroding the technology competence of the firm. Thus, a negative quadratic relationship (inverse $U$ ) is proposed between collaborations with current customers, lead users and major suppliers and technology competence of firms ( $\mathrm{H} 1 \mathrm{a}, \mathrm{H} 2 \mathrm{a}$, and $\mathrm{H} 3 \mathrm{a}$, respectively). Our competing hypotheses (H1b, H2b, and $\mathrm{H} 3 \mathrm{~b}$, respectively) focus on the potential of positive linear relationships for these same links. Finally, we propose that technology competence will have a positive linear impact on firm performance $(\mathrm{H} 4)$.

\section{Current Customer Collaboration}

Having market knowledge has long been considered a key component of product innovation (Atuahene-Gima, 1996; Jaworski \& Kohli, 1993). In turn, product innovation has been recognized as a 
key facilitator for organizational learning and overall firm success (Danneels, 2002). This study explores sub-components of market knowledge, namely collaborative relationships that companies have with their current customers, among others, in the context of technology competence for NPD. For new products to be effectively developed and ultimately successful in the marketplace, companies must link customer knowledge with technology competence (Danneels, 2002). Among several aspects, customer knowledge includes a firm's understanding of customer needs and preferences along with the strength of communication channels between companies and their customers that facilitate information exchange during development and commercialization of new products (Danneels, 2002). Similarly, technology competence includes a host of strengths, including engineering and manufacturing know-how (Danneels, 2002; Su, Chen \& Sha, 2006). As such, knowledge underpins competence, which in turn, underpins a company's product or service in the marketplace (Styhre, 2002).

Developing new products with existing customers typically leads to what is termed exploitation or incremental innovation.Collaborations with existing customers allow companies to invoke existing customer and technology competencies to achieve further optimization ( $\mathrm{Su}$, Chen \& Sha, 2006). However, Danneels (2002) identified a hybrid strategy among a small set of companies in which customer knowledge is used to develop new technology competence. More specifically, firms can leverage their strengths surrounding current customer competencies in the NPD arena by building additional technology competence to satisfy more of their existing customer's needs.

Yet, it has been argued that collaborations with current customers can ultimately stifle innovation as it puts the needs of current market segments at the forefront and does not promote more novel innovations (Faems, Van Looy \& Debackere, 2005). Said another way, existing customers often have interest in maintaining the status quo and corresponding competencies instead of pushing the frontier. In essence, existing customers may hold companies captive to current technology trajectories even when new frontiers emerge. This makes companies vulnerable to rivals, not tethered by current customer constraints, who pursue more radical technology trajectories (Christensen, 1997; Laursen, 2011).

Therefore, we posit that current customer collaboration impacts the firm's technology competence in a curvilinear fashion (inverse U), first having a positive influence as the firm increases its technological expertise and skills to take advantage of new product ideas, then having a negative effect as the firm's heavy over-reliance on these inputs stifles their push toward state of the art knowledge. Alternately, we posit a positive linear relationship in keeping with organizational learning principles suggesting that collaborations with current customers will continue to propel technology competence development. Specifically, we offer:

\section{H1a: The relationship between current customer collaboration and technology competence of the firm is curvilinear (an inverse U-shape). \\ $H 1 b$ : The greater the degree of current customer collaboration, the greater the degree of technology competence.}

\section{Lead User Collaboration}

Lead users are noted to be best at stretching the firm with new ideas for radical innovation and exploration (Lilien et al., 2002; Danneels, 2002). These ideas, as opposed to those from current customers, are strategically more valuable to the firm (Lilien et al, 2002). Collaborations with nontraditional lead users will aid firms in information acquisition and idea generation, bringing in diverse knowledge and aiding in removing bias created from solely focusing on internal R\&D activities, current customers, or key suppliers. Hence, the knowledge that comes from lead users can have a positive impact on the firm's technology competence as it integrates data and information obtained into the firm's R\&D processes, building technology competencies among others.

Lead user collaboration can be classified as performing a dynamic role of reconfiguration and transformation, among others (Tinoco, 2009). Collaborations with lead users can promote organizational learning, resulting in new routines and processes, and allow the organization to sense changes in the 
environment with respect to emerging market needs and technologies, providing impetus to the firm to push its technology frontier and position, reconfigure, and transform itself for the future.

Conversely, transforming and integrating novel lead user knowledge into new competencies is challenging and difficult, especially in high technology industries (Chang \& Taylor, 2016), which may negatively impact the level of technology competence developed as a result. Moreover, the characteristics and needs of innovators and lead users are not the same as other segments in the product life cycle (Moore, 2002). These entities expect innovative benefits and solutions to their needs early in the product life cycle and are at the leading edge of important market trends (von Hippel, 1986). They have different motivations behind new product ideas, partially because they are dissatisfied with current products and uses (e.g. Franke, von Hippel \& Schreier, 2006; Schuhmacher \& Kuester, 2012). Lead users may be limited by focusing on their own motivations and benefits, having negative implications for fruitful and relevant enhancements in technology competence. Moreover, over-reliance on lead users may lead to unnecessary or inappropriate radical innovations (Wind \& Mahajan, 1997) that may be out of touch with the current market or too far ahead of their time.

Therefore, based on the arguments above, we posit that lead user collaboration influences the firm's state of the art technology competence in a curvilinear fashion (inverse U), first having a positive influence as the firm increases its technological expertise and skills to take advantage of lead user novel input, then having a negative effect as the firm's is challenged by efficacy of knowledge integration, technological feasibility, and lead user characteristics that are ultimately detrimental. Alternately, we posit a positive linear relationship suggesting that collaborations with lead users will continue to propel technology competence development.

\section{H2a: The relationship between lead user collaboration and technology competence of the firm is curvilinear (an inverse U-shape). \\ $H 2 b$ : The greater the degree of lead user collaboration, the greater the degree of technology competence.}

\section{Supplier Collaboration}

Research indicates that the nature of competitive advantage has shifted from the manufacturer to the supply chain (Ketchen \& Giunipero, 2004; Lambert \& Cooper, 2000; Lambert \& Pohlen, 2001). With respect to competitive advantage in new product innovation, suppliers can be involved in the manufacturer's innovation and technology development from its early stages in conceptualization and design of new innovative products, in supplier willingness and readiness to invest and share new technologies, in using their skills and expertise, and in generating ideas (Henke \& Zhang, 2010; Swink \& Mabert, 2000). As technology product life cycles shorten, manufacturers look to suppliers for knowledge, skills, information and expertise that are communicated and exchanged via collaborative relationships.

Suppliers and co-suppliers contribute complementary knowledge and skills, new materials and components, and prized advanced technologies, all of which can have positive influences on the firm's competencies (Ritter \& Gemünden, 2004). Interorganizational relationships between entities that are characterized by trust, solid communication, and expectations that both parties accrue competitive advantages as a result of the relationship lead to more positive supplier attitudes toward co-innovation (Yeniyurt, Henke \& Yalcinkaya, 2014). Co-innovation enhances organizational learning and skill development for both parties.

As with customers and lead users, heavy reliance on suppliers may prove detrimental to the growth of the manufacturer's own level of technology competence. Suppliers have been noted to have a vested interest in more exploitative behaviors, having a dampening effect on growing competencies beyond existing technologies (e.g. Christensen \& Overdorf, 2000). On the flip side of the collaboration, buyers who have established strong ties with suppliers perceive less technological change in the environment and have higher switching costs (Weiss \& Heide, 1993). These ties may insulate manufacturers from detecting and/or acting on pertinent changes occurring in technology and in market environments (Weiss \& Heide, 1993), stifling a firm's desire or ability to grow its own technology competence in response to these 
changes. Additionally, buyers have been noted to fill gaps in their technology-infused product portfolios with supplier innovations and technologies (Gianiodis, Ellis, \& Secchi, 2010). While on the surface this strategy should lower costs and risks for the manufacturer, the implication is that heavy reliance on supplier innovations and technologies may limit the manufacturer's own quest for technology competence advancements. Lastly, technology management studies identify suppliers as having a more substantial impact on a firm's production process and incremental product innovations (e.g. Utterback, 1994). These types of innovations, more frequent at the end of the industry life cycle, will not drive state of the art competencies.

The arguments above suggest that supplier collaboration may have both positive and negative impacts on a manufacturer's own technology competence. While suppliers have been noted to have a positive impact on the manufacturer innovations, we also believe that they can have a positive impact on the technology competence of the firm as they drive each other's skill and expertise growth via knowledge exchange and co-innovation. Yet, extreme dependence on a major supplier may negatively impact the manufacturer's quest to build its technology competence, implying a curvilinear relationship. Hence, we offer the following hypotheses:

H3a: The relationship between supplier collaboration and technology competence of the firm is curvilinear (an inverse U-shape).

$H 3 b$ : The greater the degree of supplier collaboration, the greater the degree of technology competence.

\section{Technology Competence and Firm Performance}

Considered an intangible process (e.g. Hamel \& Prahalad, 1994; Nelson \& Winter, 1982), technology competence plays a significant role in the development and design of new product innovations and firm performance. Further, it is one of the most germane competencies for long term strategies (e.g. Malerba \& Marengo, 1995). Continuous renewal of and/or adding new competence is critical for sustained competitive advantage, particularly in dynamic environments (McGrath, 2001).

A firm that proactively builds technology competence that pushes state of the art and facilitates innovative product development has greater firm performance (e.g. Hao \& Yu, 2011), competitive performance (e.g. Malerba \& Marengo, 1995), innovation success (Ritter \& Gemünden, 2004), and return on assets (Carayannis \& Alexander, 2002). This link between continuous knowledge development and firm performance is a core tenet of organizational learning theory. Thus, it is hypothesized that

H4: The greater the degree of technology competence of the firm, the greater the degree of firm performance.

\section{METHOD}

\section{Data Collection}

Cross-sectional survey research via self-administered questionnaire was chosen as the most appropriate avenue for this study. In this context, survey research allows a better depiction and understanding of collaborative networks and their influence on a firm's technology competence and firm performance from the viewpoint of the top executives leading the firm. Disadvantages of questionnaire use were reduced by using response rate improvement methods promoted by Dillman (2000) and modified according to suggestions by Cycyota and Harrison (2006) for executive populations.

The sampling frame consisted of US high technology manufacturers with a minimum firm age of five years. Considering the model includes technology competence as the central construct, high technology industries were the appropriate choice. The American Electronics Association (AEA) was consulted as to the link between the definition of a high technology industry, that is, an industry that is a maker/creator of technology (Platzer, Novak \& Kazmierczak, 2003), and the corresponding North American Industrial Classification System (NAICS) codes, limited by this study to manufacturers. Accordingly, nine high 
technology manufacturing industries were chosen for this study, including communications equipment, computer equipment, consumer electronics, electronic components, semiconductors, defense electronics, measuring and control instruments, electromedical equipment and photonics.

Using the chosen industries, both public and private corporations for the sampling frame were drawn from CorpTech, Directory of Technology Companies. Once the sampling frame was constructed, a sample of 1000 corporations was drawn by systematic sampling in order to draw an equivalent subsample from each of the nine overarching industry categories to increase generalizability across high technology industries. The intended respondents for this study were chief executive officers (CEOs)/presidents/chairman and vice presidents at the corporate level. To ensure that individuals had an equal breadth and depth of firm knowledge, respondents were limited to these select individuals in the upper echelon of the corporation.

Common method bias was controlled by surveying two respondents per firm, when possible; by incorporating the suggested questionnaire improvement techniques of Dillman (2000) and Podsakoff, MacKenzie, Lee and Podsakoff (2003) i.e., counterbalancing, reverse coding of items, etc.; and by collecting secondary data. Secondary data were collected from the same CorpTech database and included firm-specific variables of firm sales over the most recent five year period, firm size, and age, in order to assess the possibility of method bias.

\section{Questionnaire Construction and Implementation}

Scales were chosen based on their relevance to this research, as well as their successful track record in previous research in terms of reliability and validity. All scales had a five-point scoring format $(1=$ strongly disagree; $5=$ strongly agree). The current customer collaboration scale was modified from Li and Calantone (1998), which captures knowledge generated from current customers on new product designs and ideas. The scale from McCardle (2005) was employed to assess lead user collaboration. This scale assesses the degree to which the firm employs lead user collaboration for new product ideas. Finally, the scale for supplier collaboration was developed to include a composite of items that reflects channel bonding and collaborative activities outlined in Day (1994). It specifically measures the level of manufacturer-supplier communication, team based mechanisms, along with product conceptualization and development.

Items for the technology competence scale were extracted from the specialized investments scale of Chandy and Tellis (1998) modified to assess the technology competence of the firm based on our construct definition. Recognizing that firm performance is a multi-dimensional construct, past research on similar investigation with respect to technology competence and impacts to firm performance was consulted as to the appropriate measures. As such, scales for market share, sales growth, return on sales, and profitability were employed.

Based on extant literature, the following variables were chosen as controls: environmental turbulence/intensity and firm size, both of which influence the level of firm performance (Anderson \& Tushman 2001; Utterback, 1994). We concentrate on technological turbulence and competitive intensity, borrowing the scales from Jaworski and Kohli (1993), as adapted by Joshi and Sharma (2004). Firm size was measured in terms of number of full-time employees. Industry was not used as a control as the sampling frame was limited to high technology industries. Additionally, variation across high technology industries was accounted for by use of these environmental controls.

Elements from Bagozzi (1996), Dillman (2000), and Cycyota and Harrison (2006) were employed for questionnaire construction, pretest, and implementation targeting executive populations. At the firm level, 1000 corporations were contacted via a three-wave mailing, achieving an effective firm response rate of $28 \%$. Test results for both common method bias and non-response bias indicated that neither were an issue in this study. Standard procedures for pre-analysis data screening were followed. 


\section{RESULTS}

To test the hypothesized relationships, partial least squares (PLS-SEM) structural equation modeling was used with the software package, SMART-PLS version 3.2.4 (Ringle, Wende \& Becker, 2014). PLSSEM is a suitable analysis approach when the research is exploratory in nature, the model contains formative constructs, and the goal is to maximize prediction (Hair, Ringle \& Sarstedt, 2011) - all of which are characteristics of our study. The measurement statistics in Table 1 demonstrate strong reliability with composite reliabilities (internal consistency) that range from 0.85 to 0.90 , exceeding the .6-.7 range for exploratory work and falling within the 0.8 to 0.9 range for more advanced work (Hair, Hult, Ringle \& Sarstedt, 2016). With average variance extracted (AVE) values exceeding 0.5, our constructs display acceptable convergent validity. Two different tests provide evidence that all constructs exhibit satisfactory discriminant validity. First, the square root of the AVE for each construct, ranging from 0.813 to 0.860 , are significantly greater than all corresponding correlations (Barclay, Higgins \& Thompson, 1995; Fornell \& Larcker, 1981). Second, an examination of the loadings confirmed that no item loaded more highly on another construct than it did on its associate construct (Barclay et al., 1995; Hulland, 1999).

TABLE 1

\section{AVERAGE VARIANCE EXTRACTED, COMPOSITE RELIABILITY, AND CONSTRUCT CORRELATION MATRIX}

\begin{tabular}{|l|r|r|r|r|l|}
\hline \multicolumn{1}{|c|}{ Construct $^{\mathrm{b}}$} & \multicolumn{1}{|c|}{ X1 } & \multicolumn{1}{c|}{ X2 } & \multicolumn{1}{c|}{ X3 } & \multicolumn{1}{c|}{ X4 } & X5 \\
\hline Current Customer Collaboration (X1) & $\mathbf{0 . 8 5}^{\mathrm{a}}$ & & & & \\
\hline Lead User Collaboration (X2) & 0.484 & $\mathbf{0 . 8 6}$ & & & \\
\hline Supplier Collaboration (X3) & 0.279 & 0.229 & $\mathbf{0 . 9 0}$ & & \\
\hline Technology Competence (X4) & 0.379 & 0.540 & 0.330 & $\mathbf{0 . 9 0}$ & \\
\hline Firm Size (X5 - control) & -0.201 & -0.134 & -0.311 & -0.228 & $\mathbf{1 . 0 0}$ \\
\hline \multicolumn{7}{|c|}{ Average Variance Extracted } & 0.661 & 0.673 & 0.702 & 0.739 & $\begin{array}{l}\text { Single } \\
\text { Item }\end{array}$ \\
\hline $\begin{array}{l}\text { a Bolded values on the diagonal are composite reliability scores. } \\
\text { bonly reflective constructs are included in the table. }\end{array}$ \\
\hline
\end{tabular}

To assess the structural model, a bootstrapping method (sampling with replacement) was used to ascertain the stability and significance of the parameter estimates. The t-values were computed on the basis of 5000 bootstrapping runs. Results of the structural model tests are shown in Table 2. The positive linear effects of current customer collaboration $(\mathrm{H} 1 \mathrm{~b})$, lead user collaboration $(\mathrm{H} 2 \mathrm{~b})$, and supplier collaboration $(\mathrm{H} 3 \mathrm{~b})$ on technology competence were supported $(\mathrm{p}<.05 ; \mathrm{p}<.01 ; \mathrm{p}<.01$ respectively). However, the proposed negative quadratic effects of current customer collaboration (H1a) and supplier collaboration (H3a) were not supported ( $\mathrm{p}>.05$ for both). H2a for a negative quadratic relationship was weakly supported with a statistically significant Beta coefficient $(\mathrm{p}<.10)$. Additionally, as summarized in Table 3, the change in adjusted R2 with the addition of the quadratic term for lead user collaboration resulted in an effect size of $\mathrm{f} 2=0.011$, considered a medium effect (Kenny, 2016). Together these values indicate that a negative curvilinear relationship, as hypothesized in $\mathrm{H} 2 \mathrm{a}$, was supported. Support was also found for the positive effect of technology competence on firm performance $(\mathrm{H} 4, \mathrm{p}<.05)$. Finally, our controls of firm size along with environmental turbulence and intensity were statistically significant in the negative direction as anticipated ( $\mathrm{p}<.05$ and $\mathrm{p}<.10$, respectively). 
TABLE 2

SUMMARY OF HYPOTHESES TEST RESULTS

\begin{tabular}{|c|c|c|c|c|c|c|}
\hline Hypotheses & Predictors & \multirow{2}{*}{$\begin{array}{c}\beta \\
0.045 \\
\end{array}$} & \multirow{2}{*}{$\begin{array}{c}t \\
\\
0.924 \\
\end{array}$} & \multicolumn{2}{|l|}{$p$} & Results \\
\hline H1a & $\begin{array}{llll}\begin{array}{l}\text { Current Customer } \\
\text { Competence }\end{array} & \text { Collaboration } \cap \text { Technology } \\
\end{array}$ & & & \multicolumn{2}{|l|}{0.356} & $\begin{array}{l}\text { Not } \\
\text { Supported }\end{array}$ \\
\hline $\mathrm{H} 1 \mathrm{~b}$ & $\begin{array}{llll}\begin{array}{l}\text { Current Customer } \\
\text { Competence }\end{array} & \text { Collaboration } \rightarrow & \text { Technology } \\
\end{array}$ & 0.145 & 2.018 & 0.022 & $* *$ & Supported \\
\hline $\mathrm{H} 2 \mathrm{a}$ & Lead User Collaboration $\cap$ Technology Competence & -0.076 & 1.886 & 0.059 & * & Supported \\
\hline $\mathrm{H} 2 \mathrm{~b}$ & Lead User Collaboration $\rightarrow$ Technology Competence & 0.302 & 4.207 & 0.000 & $* * *$ & Supported \\
\hline $\mathrm{H} 3 \mathrm{a}$ & Supplier Collaboration $\cap$ Technology Competence & 0.055 & 1.134 & 0.257 & & $\begin{array}{l}\text { Not } \\
\text { supported }\end{array}$ \\
\hline $\mathrm{H} 3 \mathrm{~b}$ & Supplier Collaboration $\rightarrow$ Technology Competence & 0.199 & 3.632 & 0.000 & $* * *$ & Supported \\
\hline $\mathrm{H} 4$ & Technology Competence $\rightarrow$ Firm Performance & 0.191 & 1.860 & 0.031 & $* *$ & Supported \\
\hline Control & Firm Size (Control) & -0.245 & 2.067 & 0.019 & $* *$ & \\
\hline Control & Turbulence (Control) & -0.142 & 1.612 & 0.054 & $*$ & \\
\hline & $\begin{array}{l}* p<.10 ; * * p<.05 ; * * * p<.01 ; \text { linear effects one tail signifi } \\
\mathrm{R}^{2} \text { (adjusted) Technology Competence (Linear Effe } \\
0.159 * \text { : }\end{array}$ & qua & e & tu & & cance \\
\hline
\end{tabular}

TABLE 3

RESULTS OF QUADRATIC EFFECT ASSESSMENT

\begin{tabular}{|c|c|c|}
\hline & $\begin{array}{c}\text { Model 1: } \\
\text { Linear Effects } \\
\end{array}$ & $\begin{array}{c}\text { Model 2: } \\
\text { Quadratic Effect with Lead User } \\
\text { Collaboration } \\
\end{array}$ \\
\hline Endogenous Constructs & $\mathbf{R}^{2}$ (adjusted) & $\mathbf{R}^{2}$ (adjusted) \\
\hline Technology Competence & 0.244 & 0.252 \\
\hline Firm Performance & 0.159 & 0.159 \\
\hline
\end{tabular}

\section{DISCUSSION}

Firms that draw from collaborations with external knowledge sources can capture benefits throughout the value chain. However, firms must make smart decisions when using and integrating collaborative input on their technology expertise decisions. For high technology B2B companies seeking to have state of the art technology expertise, there appears to be no systemic downside risk or negative tipping point in technology competence development when working with current customers. This is not necessarily contrary to Christensen (1997) who argued that relying on current customers for new creative product development would lead to exploitation over exploration. Instead, this study indicates that purposeful collaborations with existing customers can be leveraged to develop technological abilities and skills, in terms of competence, that continually push the frontier and can be useful in both exploitative and explorative product innovations. This evidence also supports Danneels (2002) theoretical assertion, 
beyond limited case study support, that hybrid leveraging strategies with customers can bear fruit in increased levels of technology competence, and ultimately, greater firm performance. Further still, these hybrid strategies can help to reduce both costs and risks for firms in their product development efforts (Danneels, 2002). Hence, firms are encouraged to meet regularly with existing customers to learn about their needs for new products. Marketing should take the lead as these interactions can involve both focal group discussions and observation of customers' operations. Moreover, it is important for firms, especially within marketing, to have systematic processes for analyzing customer information to ensure that it is fully integrated in new product design.

Similarly, channel bonding activities with major suppliers can also enhance a firm's technology competence with no systemic downside risk of over-involvement. Integration efforts begin with a culture of open communications between firms and major suppliers that is encouraged across functional boundaries and at all levels. This culture of openness should extend to conflict resolution efforts in which joint problem-solving with major suppliers is encouraged over arms-length negotiations. Team-based approaches can help to foster activity coordination and information exchange and should be extended to new product conceptualization, development, and scheduling. Once again, marketing has a key role in such boundary-spanning activities.

While collaborative efforts with lead users are initially effective, too much collaboration may eventually detract from technology competence. This does not mean that firms should not seek input from lead users. In fact, according to our model, the initial benefits of working with lead users outpaces both collaborations with current customers and major suppliers. Indeed, seeking out experts in the uses and functions of a firm's current products can aid in better understanding the needs of other customers and push technology skill development forward. However, firms must maintain discipline in working with lead users as over-involvement can lead to diminishing returns. This is likely due to inherent risks associated with lead users. Their interests are more likely to be idiosyncratic, technologically infeasible, or out of touch with the current marketplace. Therefore, it is imperative for managers to quickly sense collaborations with lead users that have limited chance for success as there are opportunity costs associated in building technology competence. As customer-facing specialists, marketers must provide insight on which relationships to pursue. Over-pursuit of the wrong lead users or over-commitment of resources in this area can cause firms to take a step backward in technological advancement.

Interestingly, Chang \& Taylor (2016) find through meta-analysis that employing business customer input into the NPD process does not clearly aid in developing new innovative products and that customer participation in low technology industries yields higher returns than in high technology industries. They also find that in technologically turbulent industries open innovation may indeed be the best approach to new products. Yet, clearly we find support that input from a firm's current customers, a significant precursor to new products, has a positive influence on technology competence.

Finally, as expected, gains in technology competence have positive direct effects on firm performance. More specifically, when firms continue to pursue state of the art technology expertise, they are more likely to achieve higher sales coupled with greater market share and overall profitability. Hence, it is imperative for firms in high technology industries to continually stay at the forefront of learning and technical skill development in order to stay a step ahead of the competition.

There were several limitations to this study which need further examination. We anticipated curvilinear relationships for both current customer collaboration and supplier collaboration, but evidence did not statistically support these hypotheses. Alternately, our lead user collaboration-technology competence curvilinear relationship was supported, but not to the degree we expected. Because of these results, further examinations are needed. Second, the concept of balance among collaborative partners was not empirically examined. This could be tested in future research as a three-way interaction. Finally, the possibility of moderators and mediators needs to be addressed to fine tune the model. 


\section{CONCLUSION}

In the ongoing study of innovation and new product development, our research indicates that external collaborations with current customers, lead users, and major suppliers are all important for high technology organizations to continually build their stock of technical expertise. These findings are important as there has been considerable debate in the literature, especially as to whether collaborations with current customers enhance or stifle innovation efforts. While we focused on technology competence, specifically, our results show that purposeful collaborations with both current customers and major suppliers can keep companies positioned on the leading edge of technology. Meanwhile, high technology firms need to pursue ideas from lead users, but should exercise caution in their competence strategies.

\section{REFERENCES}

Anderson, P., \& Tushman, M. L. (2001). Organizational environments and industry exit: The effects of uncertainty, munificence and complexity. Industrial and Corporate Change, 10(3), 675-711.

Armstrong, J. S., Brodie, R. J., and Parsons, A. G. (2001). Hypotheses in marketing science: Literature review and publication audit. Marketing Letters, 12(2), 171-187.

Atuahene-Gima, K. (1996). Market orientation and innovation. Journal of Business Research, 35(2), 93103.

Barclay, D., Higgins, C., \& Thompson, R. (1995). The partial least squares (PLS) approach to casual modeling: Personal computer adoption and use as an illustration. Technology Studies, 2: 285-309

Bagozzi, R. P. 1996. Measurement in marketing research: Basic principles of questionnaire Design. Principles of Marketing Research, Oxford: Blackwell Publishers.

Carayannis, E. G., \& Alexander, J. (2002). Is technological learning a firm core competence, when, how and why? A longitudinal, multi-industry study of firm technological learning and market performance. Technovation, 22(10), 625-643.

Chandy, R. K., \& Tellis, G. J. (1998). Organizing for radical product innovation: The overlooked role of willingness to cannibalize. Journal of Marketing Research, 35(4), 474-487.

Chang, W., and Taylor, S. A. (2016). The effectiveness of customer participation in new product development: A meta-analysis. Journal of Marketing, 80(1), 47-64.

Christenson, C. (1997). The innovator's dilemma. Harvard Business School Press, Cambridge, Mass.

Christensen, C. and Overdorf (2000). Meeting the challenge of disruptive change. Harvard Business Review 78(2), 66-76.

Cycyota, C. and Harrison, D. (2006). What (not) to expect when surveying executives: A meta- analysis of top manager response rates and techniques over time. Organizational Research Methods, $9(2)$, 133-160.

Danneels, E. (2002). The dynamics of product innovation and firm competences. Strategic Management Journal, 23(12), 1095-1121.

Day, G. S. 1994. The capabilities of market driven organizations, Journal of Marketing, 58, 37-53.

Dillman, D. A. (2000). Mail and internet surveys: The tailored design method. New York: John Wiley \& Sons, Inc.

Dyer, J. H. (1998). The relational view: Cooperative strategy and sources of interorganizational competitive advantage. Academy of Management Review, 23(4), 660-79.

Ellis, S. C., Henke, John W. Jr, \& Kull, T. J. (2012). The effect of buyer behaviors on preferred customer status and access to supplier technological innovation: An empirical study of supplier perceptions. Industrial Marketing Management, 41(8), 1259-1269.

Faems, D., Van Looy, B., \& Debackere, K. (2005). Interorganizational collaboration and innovation: Toward a portfolio approach. Journal of Product Innovation Management, 22(3), 238-250.

Fornell, C., \& Larcker, D. F., (1981). Evaluating structural equation models with unobservable variables and measurement error. Journal of Marketing Research, 18(1), 39-50. 
Franke, N, von Hippel, E., and Schreier, M. (2006). Finding commercially attractive user innovations: a test of lead-user theory. Journal of Product Innovation Management, 23(4), 299-300.

Gianiodis, P. T., Ellis, S. C., \& Secchi, E. (2010). Advancing a typology of open innovation strategies. International Journal of Innovation Management, 14(4), 531-572.

Greco, M., Grimaldi, M., \& Cricelli, L. (2015). Open innovation actions and innovation performance: a literature review of European empirical evidence. European Journal of Innovation Management, $18(2), 150-171$.

Gulati, R. (1998). Alliances and networks. Strategic Management Journal, 19(4), 293-317.

Hair Jr, J. F., Hult, G. T. M., Ringle, C., \& Sarstedt, M. (2016). A Primer on Partial Least Squares Structural Equation Modeling (PLS-SEM). Sage Publications.

Hair, J.F., Ringle, C.M., and Sarstedt, M. (2011). PLS SEM: Indeed a silver bullet. Journal of Marketing Theory and Practice, 19(2), 139-151.

Hamel, G. and C.K. Prahalad. (1994). Competing for the future. Boston: Harvard Business School Press.

Hao, S., \& Yu, B. (2011). The impact of technology selection on innovation success and organizational performance. Ibusiness, 3(4), 366-371.

Henke, J. W., \& Zhang, C. (2010). Increasing supplier-driven innovation. MIT Sloan Management Review, 51(2), 41-46.

Hulland, J. (1999). Use of partial least squares (PLS) in strategic management research: A review of four recent studies. Strategic Management Journal 20(2), 195-204.

Jaworski, B.J. and Kohli, A. J. (1993). Market orientation: antecedents and consequences. The Journal of Marketing, 53-70.

Joshi, A. W., \& Sharma, S. (2004). Customer knowledge development: antecedents and impact on new product performance. Journal of Marketing, 68(4), 47-59.

Kenny, D. (2016). Moderation. Retrieved from http://davidakenny.net/cm/moderation.htm

Ketchen, D. J. and Giunipero, L. (2004). The intersection of strategic management and supply chain management. Industrial Marketing Management, 33(1), 51-56.

Kogut, B. (1988). Joint ventures: Theoretical and empirical perspectives, Strategic Management Journal, 9(4) 319-332.

Lambert, D.M. and Cooper, M.C. (2000). Issues in supply chain management. Industrial Marketing Management, 29(1), 65-83.

Lambert, D.M. and Pohlen, T.L. (2001). Supply chain metrics. International Journal of Logistics Management, 12(1), 1-19.

Laursen, K. (2011). User-producer interaction as a driver of innovation: costs and advantages in an open innovation model. Science and Public Policy, 38(9), 713-723.

Li, T. and Calantone, R. (1998). The impact of market knowledge competence on new product advantage: Conceptualization and empirical examination. Journal of Marketing, 62(4), 13-29.

Lilien, G., Morrison, P., Searls, K., Sonmack, M., and von Hippel, E. (2002). Performance assessment of the lead user idea-generation process for new product development. Management Science, 48(8), 1042-1059.

Malerba, F., \& Marengo, L. (1995). Competence, innovative activities and economic performance in Italian high-technology firms. International Journal of Technology Management, 10(4-6), 461477.

March, J. G. (1991). Exploration and exploitation in organizational learning. Organization Science, 2(1), 71-87.

McCardle, M. (2005). Market foresight capability: Determinants and new product outcomes. Dissertation.

McGrath, R.G. (2001). Exploratory learning, innovative capacity, and managerial oversight. Academy of Management Journal. 44(1), 118-131.

Moore, Geoffrey A. (2002), Crossing the Chasm: Marketing and Selling High-Tech Products to Mainstream Customers. New York: HarperCollins Publishers

Nelson Richard, R., \& Winter Sidney, G. (1982). An evolutionary theory of economic change. Harvard Business School Press, Cambridge. 
Platzer, M. D., C. A. Novak, and M. F. Kazmierczak. (2003). Defining the high-tech industry: AeA's new NAICS-based industry definition, William T. Archey (Ed.) vol. 2005. Washington, DC: American Electronics Association.

Podsakoff, P. M., MacKenzie, S. B., Lee, J. Y., \& Podsakoff, N. P. (2003). Common method biases in behavioral research: a critical review of the literature and recommended remedies. Journal of Applied Psychology, 88(5), 879.

Powell, W., Koput, K. and Smith-Doerr, L. (1996). Interorganizational collaboration and the locus of innovation: networks of learning in biotechnology. Administrative Science Quarterly, 41(1), 116145.

Ringle, Christian M., Wende, Sven, and Becker, Jan-Michael. (2014). Smartpls 3. Hamburg: SmartPLS.

Ritter, T. and Gemünden, H.S. (2004). The impact of a company's business strategy on its technological competence, network competence and innovation success. Journal of Business Research, 57(5), 548-556.

Schuhmacher, M. C., \& Kuester, S. (2012). Identification of Lead User Characteristics Driving the Quality of Service Innovation Ideas. Creativity \& Innovation Management, 21(4), 427-442.

Styhre, A. (2002). The knowledge-intensive company and the economy of sharing: Rethinking utility and knowledge management. Knowledge and Process Management, 9(4), 228-236.

Su, C. T., Chen, Y. H., \& Sha, D. Y. (2006). Linking innovative product development with customer knowledge: A data-mining approach. Technovation, 26(7), 784-795.

Swink, M. L., \& Mabert, V. A. (2000). Product development partnerships: Balancing the needs of OEMs and suppliers. Business Horizons, 43(3), 59-68.

Tinoco, J. K. (2009). Strategic Ambidexterity: An Indispensable Capability in the Face of Change, In Proceedings of the 2009 Atlanta Conference on Science and Innovation Policy, ed. Susan E. Cozzens and Pablo Catalán. IEEE.

Tinoco, J. K. (2014). Double Dealing: The Influences of Diverse Business Processes on Organizational Ambidexterity. Academy of Strategic Management Journal, 13(2), 87-110.

Varadarajan, P. R. \& S. Jayachandran, S. (1999). Marketing strategy: An assessment of the state of the field and outlook. Journal of the Academy of Marketing Science, 27(2), 120-143.

Von Hippel, E. (1986), Lead users: A source of novel product concepts. Management Science, 32(7), 791-805.

Weiss, A. M., \& Heide, J. B. (1993). The nature of organizational search in high technology markets. Journal of Marketing Research 30(2), 220-233.

Utterback, J. (1994). Mastering the Dynamics of Innovation. Boston, MA: Harvard Business School Press.

Wind, J. and Mahajan, V. (1997). Issues and opportunities in new product development: An introduction to the special issue. Journal of Marketing Research, 34(1), 1-12.

Yeniyurt, S., Henke, J. W., \& Yalcinkaya, G. (2014). A longitudinal analysis of supplier involvement in buyers' new product development: working relations, inter-dependence, co-innovation, and performance outcomes. Journal of the Academy of Marketing Science, 42(3), 291-308. 